\title{
AFGHANISTAN-PAKISTAN TRADE RELATIONS
}

\author{
Zareen F. Naqvi* \\ SASPR
}

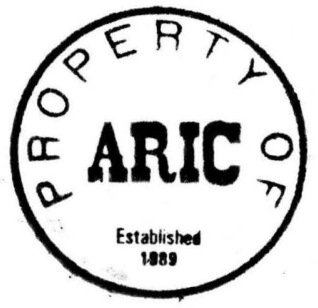

Abstract: This paper is based on a study commissioned by the World Bank's South Asia Region as part of its "Watching Brief" strategy for Afghanistan. Total trade between Afghanistan and Pakistan in 1997 is conservatively estimated at about \$2.5 billion, largely consisting of unofficial re-exports from Afghanistan to Pakistan. The long and porous border between the two countries, the need for basic goods in Afghanistan's wartorn economy, weak border controls, high import tariffs in Pakistan on goods prone to smuggling, and the low cost/risk of smuggling are important reasons behind the large and growing unofficial trade between the two countries. There is also evidence of expansion of official and unofficial trade in locally-produced goods between the two countries, which is likely to increase substantially if there is peace and post-war reconstruction in Afghanistan. The impact of bilateral trade with Pakistan on Afghanistan's economy has been positive overall, as manifested in the modest prosperity that has emerged in southern and western Afghanistan. In addition, cross-border trade provides essential goods and generates some revenues for Afghan authorities. The impact on Pakistan's economy has been mixed -- certain industries benefit from low cost smuggled inputs and export products to Afghanistan, while those producing importcompeting goods have been harmed. Moreover, the government of Pakistan is losing substantial revenues due to tax evasion and fungibility of routes through which unofficial imports enter the country. This study, which was conducted on the Pakistani side of the border, raises a number of issues and questions for further research.

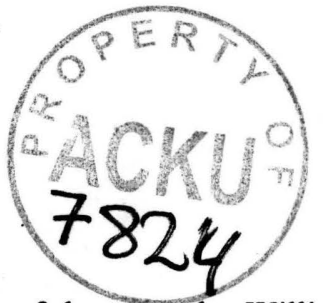

* I would like to appreciate the helpful comments on this study and earlier drafts of the paper by William Byrd. I would also like to acknowledge the assistance provided by Shams ur Rehman, Faqir Hussain Shamsi, and Mahjabeen Husain in data collection and preparation of parts of the paper. I would also like to thank our consultants, Dr. Zafar Mahmood and Abdul Ghafoor Masoom, for their work on the study. 


\section{INTRODUCTION}

Afghanistan has been a country in conflict for the last two decades, resulting in substantial destruction of its economy and formal economic institutions. Information regarding current economic activities and economic structures is very sparse, partly because institutions which collected information have become dysfunctional, and also because the recorded economy has almost certainly shrunk relative to the informal economy, compared to the pre-war period. Discussions on the economy are thus based on patchy, anecdotal evidence and impressions, rather than any solid data. This study is an attempt to gain a better understanding of a significant segment of the Afghan economy -trade relations between Pakistan and Afghanistan.

Pakistan was chosen as the partner country of focus for this study of Afghanistan's trade for several reasons. First, there is evidence of growth in the trade sector in Afghanistan in recent years, mainly related to the cross-border trade (primarily smuggling) with Pakistan, which also seems to be a major factor behind the apparent modest prosperity border cities of southern and western Afghanistan. Second, there seem to be strong linkages between the Pakistani economy with parts of eastern and southern Afghanistan, which is largely manifested in trade activities between the two countries. Third, the impact of smuggling from Afghanistan seems to be fairly sizable for the Pakistani economy as well. Fourth, it was easier from a logistical point of view to conduct this study from Pakistan. The Bank, which is currently following a "Watching Brief" strategy for Afghanistan, ${ }^{1}$ conducts its limited work on Afghanistan from Pakistan. ${ }^{2}$ Fifth, land-locked Afghanistan has a transit trade agreement with Pakistan which is used for transporting the bulk of Afghanistan's trade; and information on this trade is readily available in Pakistan. It is envisaged that at a later stage, if conditions are feasible, similar studies would be conducted to learn more about Afghanistan's trade relations with other neighboring countries.

The primary goal of this study was to estimate the magnitude and composition of trade between Afghanistan and Pakistan. As the official trade is very small, the main focus was on ascertaining the extent of unofficial trade flows between the two countries. A principal objective was to understand the nature and mechanisms of bilateral trade in order to gauge the potential for Afghanistan's trade relations with Pakistan in a post-war scenario.

\footnotetext{
${ }^{1}$ As postulated in the Bank's Framework paper on Post-conflict Reconstruction (1997) for dealing with countries in conflict.

2 Most UN agencies, donors, and NGOs dealing with Afghanistan also are currently based in Pakistan.
} 


\section{MAGNITUDE AND MECHANISMS OF BILATERAL TRADE}

Total bilateral trade between Afghanistan and Pakistan is conservatively estimated at $\$ 2.5$ billion in $1996 / 97$, equivalent to approximately $48 \%$ of Afghanistan's roughly estimated GDP and around 12-13\% of Pakistan's total trade. ${ }^{3}$ This trade can be disaggregated into four categories. (See Table 1).

1) Official trade between the two countries in locally produced goods, which is very small and accounted for approximately $2 \%$ of estimated total bilateral trade in $1996 / 97$.

2) Unofficial trade in locally-produced goods worth $\$ 357$ million, which comprises $14 \%$ of estimated total Afghanistan-Pakistan trade; this is very similar in composition to the official trade, but is estimated at 13 times the value of official trade.

3) Trade under the 1965 Afghan Transit Trade Agreement (ATTA), which primarily comprises of imports bound for Afghanistan. The ATTA trade is viewed as a major source of smuggling into Pakistan, and its composition and magnitude have undergone considerable changes in recent years.

4) Unofficial re-exports of goods from Afghanistan into Pakistan, estimated at \$ 1.96 billion ( $84 \%$ of the total trade) in 1997.

The bulk of trade between Afghanistan and Pakistan takes place through two main routes: Torkhum near Peshawar (NWFP) and Chaman-Weish near Quetta (Balochistan). There are many smaller routes all along the Afghanistan-Pakistan border through which unofficial trade in locally produced goods takes place. Three which the study covered were Parachinar-Miran Shah (North Waziristan), Chitral, and Wana (South Waziristan). Map 1 shows the main trade routes between Afghanistan and Pakistan.

Most of the unofficial re-exports are smuggled through various routes into Afghanistan, including sea routes from the Middle East (Dubai) and Southeast Asian markets into Iran (Bander Abbas); land routes through Iran and Turkmenistan; air routes into Afghanistan from the Middle East and India (India reportedly offers a subsidy on airfreight into Afghanistan); and rail and land routes from the Central Asian Republics (CARs) and Russia (these countries give concessions on transit goods coming via Vladivostok). Islam Qila and Torghundi in western Afghanistan are the main points at

3 Ministry of Commerce officials in Pakistan appear to consider that this estimates is very high. According to them the size of the unofficial imports and re-exports from Afghanistan is closer to $\$ 500$ million annually. Their estimates are based on the size of the ATT (roughly $\$ 200$ million) and rough guesses of another $\$ 300$ million worth of smuggling from Dubai and Iran via Afghanistan. On the other hand, the estimates presented in this paper are based on field work and detailed interviews with traders, transporters, shippers and handlers, etc. While there are serious limitations in this methodology, it is likely that the resulting estimates would not be off by more than $10-25 \%$ in either direction, and that perhaps the extent of the trade between Afghanistan and Pakistan is underestimated. 


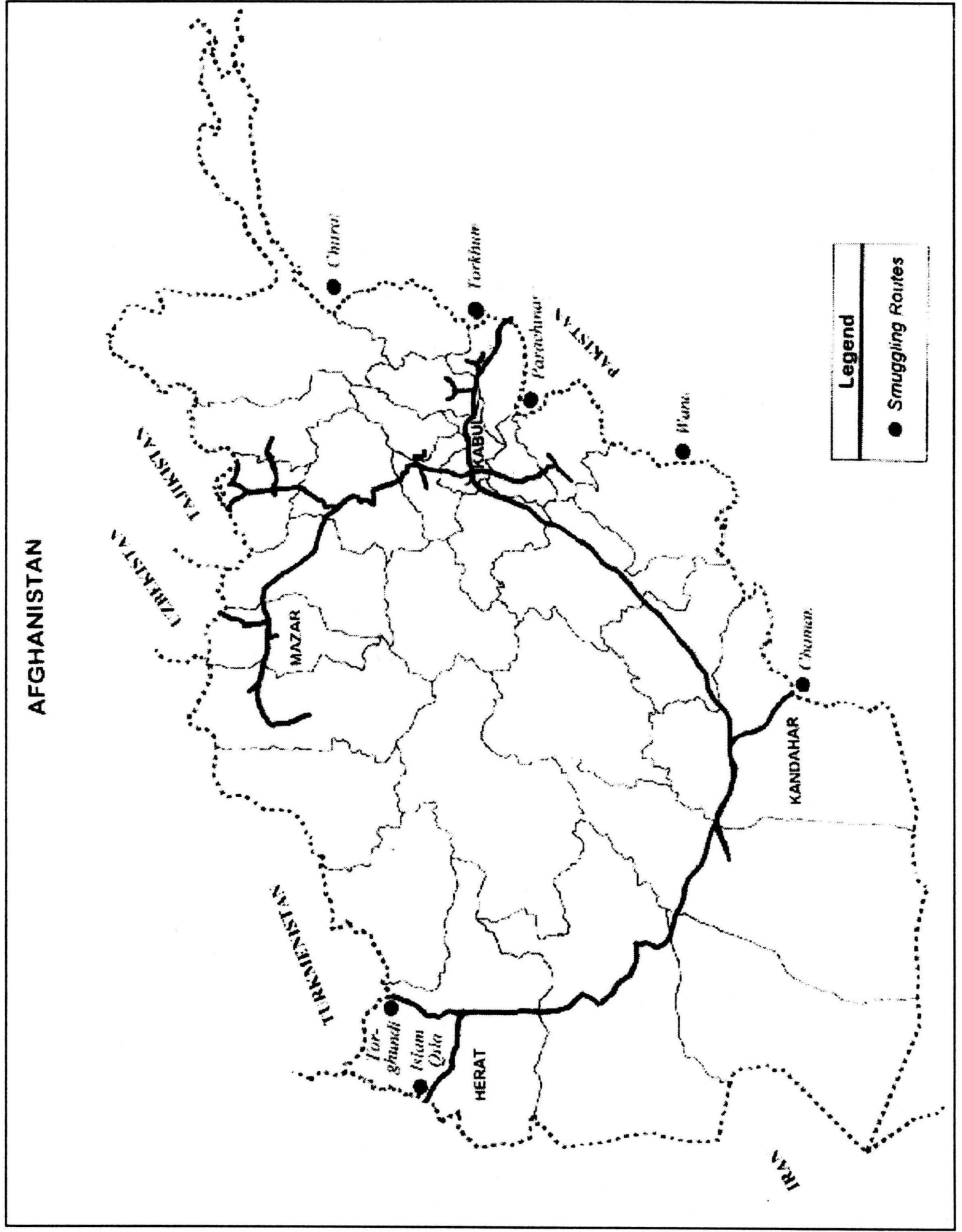


which Pakistan-bound goods enter Afghanistan via land and rail routes, while Jalalabad and Kandahar are the main transshipment points for air-routes. These goods enter Pakistan through various land routes along the porous Afghanistan-Pakistan border. The official routes under the ATT are through the port of Karachi to Chaman (Balochistan) and Peshawar (NWFP) in Pakistan, for further transit into Afghanistan. A large share of goods under ATT are believed to end up in Pakistan, either by never crossing the border, or after crossing the border promptly re-entering Pakistan via multiple smuggling routes. Thus Afghanistan still seems to be an important conduit for international trade which existed centuries ago on the famous "Silk Route" between China and Europe.

Locally-produced goods are reported to be bartered or traded in Pakistani rupees. Unofficial re-exports from Afghanistan, which form the bulk of the trade, are financed using the Hawala (referral) system whereby traders make local currency payments against foreign currency payments abroad by counterpart financiers. The traders also use Pakistan's open markets for foreign exchange to buy foreign currencies and use banks located in Pakistan to make payments against imported merchandise. It is suspected that financing of re-exports from Afghanistan may be an important mechanism for laundering drug money.

\section{Trade in Locally-Produced Commodities}

Over the past 25 years, official trade between Afghanistan and Pakistan has been very limited, as shown in Figures 1 and 2. Pakistan's official trade with Afghanistan is reported at approximately $\$ 48-49$ million annually in the last two years, which comprises $0.2-0.3 \%$ of Pakistan's total trade. This represents a substantial increase over the early 1990 s, when official trade was only $\$ 25-26$ million annually. Even in the pre-war period (i.e. before 1978), the official bilateral trade never accounted for more than $1-1.5 \%$ of Pakistan's total trade.

Trade relations between the two countries have become stronger during the 1990s as closer political relations have developed. Falling domestic production and exportable surpluses and high demand for basic goods in a war-torn economy are factors which may have increased cross-border trade with Pakistan. The size and composition of official trade could also be influenced by the direction of Pakistan's trade and changes in its trade policies. However, the official data portrays a very incomplete picture of trade relations between Afghanistan and Pakistan, because it does not account for the thriving unofficial trade in locally produced and imported goods. To get a full picture, we take a closer look at components of the official and unofficial trade below. 


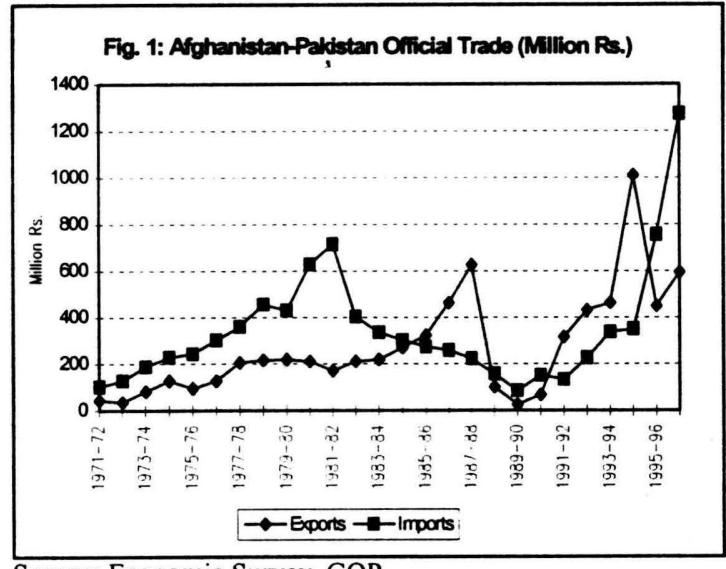

Source: Economic Survey, GOP.

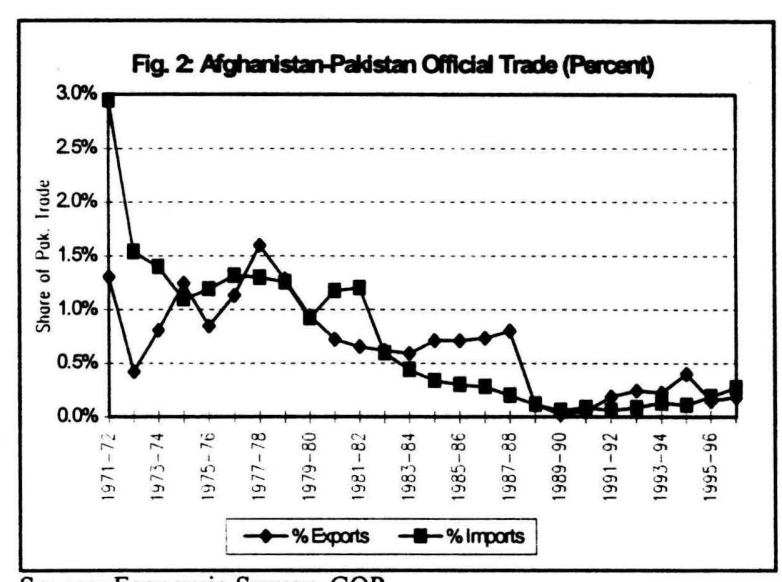

Source: Economic Survey, GOP

The composition of legal and unofficial exports is quite similar (See Annex Tables A1 \& A2). Rice, sugar, and "ghee" (hydrogenated oil) account for $1 / 3$ of both legal exports (in 1997/98) and unofficial exports (in 1997). The biggest item in unofficial exports from Pakistan was wheat flour ("atta"), which is a staple food item in Afghanistan. This comprised close to $1 / 4$ of unofficial exports but does not show up in legal exports because of the official ban on wheat/flour exports following the wheat/flour crisis in Pakistan during the spring/summer of 1997. There are indications that the pattern of trade in locally produced goods, which has evolved over a period of prolonged conflict in Afghanistan, does not undergo rapid changes, but that changes in official policies in the two countries shift trade flows between official and unofficial channels.

There have been some changes in the composition of exports from Pakistan to Afghanistan over the last decade. In the mid-1980s to early 1990s, exports from Pakistan largely consisted of food items and raw materials for Afghanistan's industries, such as yarn and textile products, metal products, and glass products. Subsequently, in recent years rice has become a major export from Pakistan through both official and unofficial channels, most likely due to the disruption of domestic supply routes in Afghanistan, where the rice-producing northern provinces, held by anti-Taliban forces until recently, have become economically cutoff from the southern and western parts of the country. Other food items such as wheat flour, ghee and edible oil, sugar, pulses, and miscellaneous food items are exported by both official and unofficial routes to Afghanistan. Other basic needs goods, such as medicines and cloth, and agricultural inputs like fertilizer, are largely exported unofficially to Afghanistan. The decline in imports of yarn/textile products from Pakistan (shown in Table A1, and also seen in Table A5 under the ATT) could partly be attributed to the decline in textile production in Afghanistan, as the war led to large-scale destruction of that country's industrial sector. There has also been an increase in official exports of plastic products (mainly plastic sheets, plastic bags, PVC pipes, etc.), cement, and construction materials in recent years, which point to the growing demand for temporary and permanent housing for returning refugees and internally displaced persons in Afghanistan. 
The composition of official and unofficial imports from Afghanistan to Pakistan (shown in Tables' A3 and A4) is indicative of the current exportable surpluses in Afghanistan and also suggestive of its export potential in a more peaceful environment. Afghanistan, being a predominantly agrarian economy, primarily exports agricultural products to Pakistan. Fresh fruits and vegetables, and dried fruits which have traditionally been important exports from Afghanistan to the Indian Sub-continent, continue to be significant. ${ }^{4}$ There has been a significant growth in exports of other agricultural products, such as lentils, herbs, and spices, in recent years, which reflects the reported growth in agricultural production in relatively peaceful areas in Afghanistan. Metal scrap, a byproduct of war-related destruction, was a sizable export from Afghanistan in the early 1990s but has fallen in value and share in recent years. Wood, mainly from the forests and woodlands in eastern and northeastern Afghanistan, has become an important legal import to Pakistan in recent years. The environmental damage caused by large-scale logging and export of wood and timber are a major cause of concern for environmental groups. In addition, hand-made carpets and rugs and precious stones are important unofficial imports from Afghanistan.

There seems to be considerable potential for expanding Afghanistan's bilateral and regional trade in a post-conflict scenario. Based on the analysis of legal and unofficial bilateral trade in locally-produced goods, Afghanistan seems to have a clear advantage in existing and newer varieties of agricultural and horticultural products. The country used to be one of the largest exporter of Karakul pelts in the past, which were auctioned in markets in London and New York and fetched hard currency for the government. Growth in livestock-related exports could have substantial potential for expanding future trade. In addition, well-established markets for hand-made carpets and rugs could be further expanded. Precious stones and jewelry exports are another area worth exploring for Afghanistan's future exports.

\section{Unofficial Re-Exports from Afghanistan to Pakistan}

More than $80 \%$ of the estimated total trade between Afghanistan and Pakistan consists of re-exports of goods or smuggling. This is not a new phenomenon but has existed for many years. Fry (1974) estimated that items officially imported into Afghanistan for unofficial re-export to Pakistan and other types of smuggling accounted for $20 \%$ of Afghanistan's total commercial trade in the early 1970s. Khan (1972) estimated that aside from sizable smuggling of locally-produced goods, unrecorded reexports from Afghanistan were also quite large. During the late 1960s, he calculated the

\footnotetext{
${ }^{4}$ These comprised close to half of total legal imports from Afghanistan to Pakistan between the mid-1980s and early 1990s, but the share has fallen to around 1/4 of the legal imports in the last two years. Fresh and dried fruits also comprise more than $1 / 3$ of unofficial imports into Pakistan, as seen in Table A4. The latter could also contain goods exported under the ATT. More information is being sought on goods exported under ATT from Pakistan government officials.
} 
latter to be in the range of Rs. $40-60$ million ( $\$ 8-12$ million) annually, equivalent to around $1.5-2 \%$ of Pakistan's imports.

The Afghan Transit Trade agreement (ATT), which allows transit facilities to Afghanistan, has been a major channel of smuggling into Pakistan. There was a rapid increase in the ATT during the 1992/93 to 1994/95 period, both in terms of value and its share relative to Pakistan's total imports. From a level close to $\$ 50$ million annually in the mid-to late $1980 \mathrm{~s}$, ATT imports increased to Rs. 3.3 billion ( $\$ 128$ million) in 1992/93 and then jumped to more than Rs. 8 billion ( $\$ 264-266$ million) during 1993/94 and 1994/95. Following the rapid growth in ATT and its adverse impact on some Pakistani industries, the government of Pakistan banned 17 items from ATT during 199295 (listed in Annex 1, Box 1), which subsequently led to a decline in ATT trade. However, there has been a resurgence in ATT imports in 1997/98, which have reached an estimated Rs. 8.9 billion ( $\$ 207$ million), equivalent to $2 \%$ of Pakistan's total imports. ${ }^{6}$

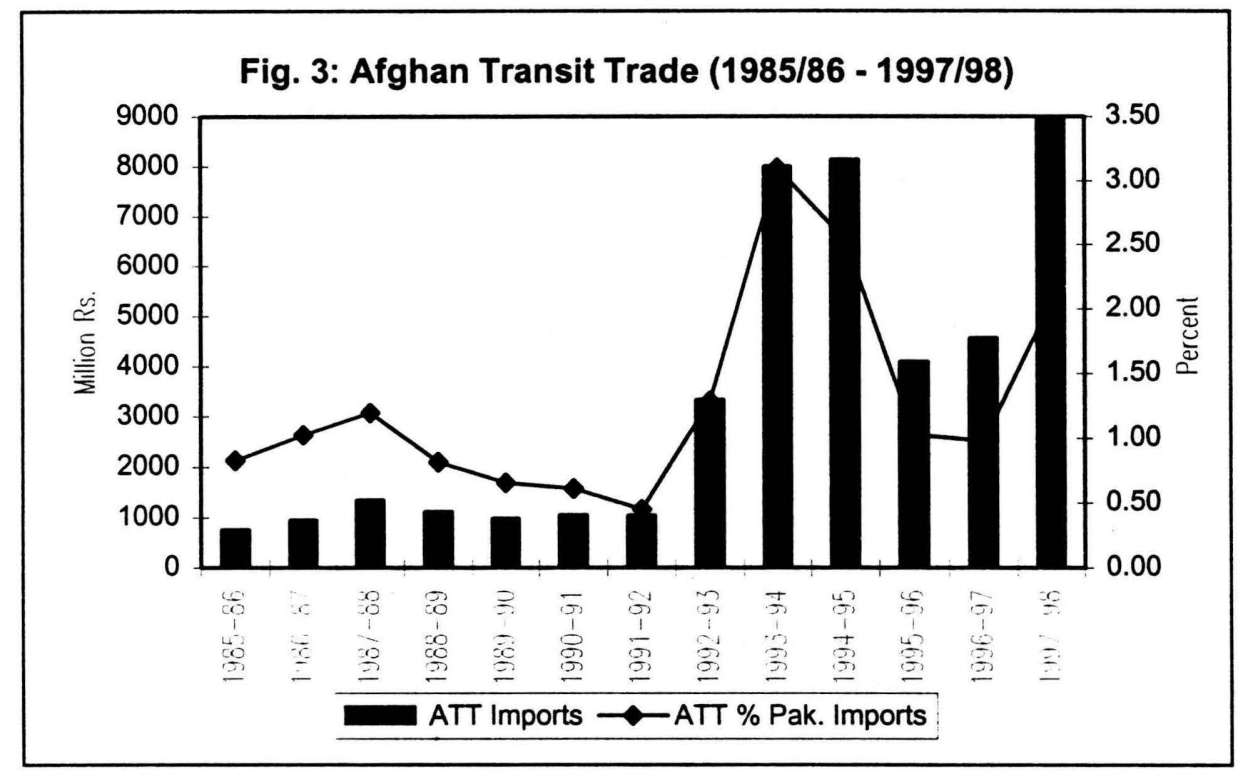

Our analysis shows that changes in government policy in Pakistan have led to changes in the composition of the ATT, but not necessarily in the overall pattern of smuggling from Afghanistan into Pakistan. During the mid-1980s to early 1990s, textile goods, yarn, tires/tubes, black tea, and electrical goods (mainly household electrical

\footnotetext{
${ }^{5}$ Khan's detailed analysis of the ATT also showed that during the 1966-69 period, the commodity composition of the ATT was not too dissimilar to that during the mid-1980s and early 1990s. Items such as tires and tubes, yarn, machinery parts, tea, and miscellaneous goods formed the bulk of goods imported under ATT.

${ }^{6}$ The actual value of ATT imports are believed to be much higher because of the widespread practice of underinvoicing and mis-reporting of items under the ATT. The sudden increase in ATT in 1997/98 largely consists of motor oil $(9.5 \%)$, glass ware/dinner sets $(7 \%)$, green tea $(5.8 \%)$, battery cells $(5.4 \%)$, electronic goods $(5 \%)$, and a variety of items categorized under sundry goods $(9.3 \%)$ and other miscellaneous items.
} 
gadgets) were important items imported under the ATT. The sudden increase in the ATT during the 1992 to '1995 period also corresponded to some changes in the structure of the trade. ${ }^{7}$ Further restrictions by the Pakistan government during 1995/96 resulted in many of these goods dropping out of the ATT (as shown in Table A5). However, these commodities now form the bulk of unofficial re-exports which are coming through land and rail routes into western Afghanistan or by air routes into eastern and southern cities in Afghanistan for further transit into Pakistan. (See Table 1). ${ }^{8}$

It seems that attempts to control smuggling by restricting goods coming through ATT -- a demand often made by industrial and trade groups in Pakistan -- have not been very successful. ATT restrictions seem to have resulted in changes in the routes though which smuggling occurs, without necessarily reducing its magnitude or changing its overall composition. Other events, such as opening of trade routes through the Central Asian Republics and their desire to integrate in the global economy, may also be important factors facilitating the flow of goods through unofficial channels. It is quite likely that the magnitude of smuggling may even have increased over the last few years, after the Taliban gained control of southern and eastern Afghanistan and general security conditions improved in these areas, which made movement of goods via land routes inside Afghanistan much easier. In addition, Iran's transit trade facility to Afghanistan through the port of Bandar Abbas may have allowed the use of land routes for re-exports into Pakistan. The reported closure of this route (in May 1997 after the brief takeover of Mazar-i-Sharif by the Taliban and closure of the Iranian embassy in the city), and the military build-up on the Iran-Afghanistan border in recent months, may be provide deterrents to smuggling into Pakistan.

It is well known that there is considerable under-invoicing of imports under the ATT. Therefore the amounts shown in official data could well be seriously underestimated and the magnitude of smuggling even larger. What proportion of ATT goods are smuggled into Pakistan? This cannot be ascertained with any degree of accuracy. Government officials in Pakistan are of the view that measures taken by them, such as detailed paperwork, sealing of consigned goods, shipment of transit goods in special railway wagons, checking of shipment invoices at several points etc., eliminate the chances of en-route diversion. But it is generally believed that despite elaborate procedures, en-route smuggling from the ATT is not inconsequential. Even if ATT-

\footnotetext{
${ }^{7}$ For instance, items like yarn and tires/tubes lost their share after being banned, whereas televisions, crockery, and household glass wares, miscellaneous electrical goods, etc. became important traded items.

${ }^{8}$ For example, television sets, which comprised $12-17 \%$ of imports under Afghan Transit trade during 1993/94 and 1994/95, disappear thereafter from the list (see Table A5), but they comprise $18 \%$ of estimated unofficial re-exports (valued at Rs. 14.8 billion) coming through Afghanistan. Similarly, banning art silk fabrics from the ATT has led to curtailment of these imports under the ATT, but they still comprised $11 \%$ of smuggled textile imports from Afghanistan in 1997, as shown in Table 1. For other products, such as tea, green tea is still being imported under the ATT, but banning of black tea imports seems to have resulted in this being smuggled through routes crossing Afghanistan.
} 
bound goods do cross the border into Afghanistan, a large share of these products come back to Pakistan. 'Busy markets for smuggled goods in towns close to the AfghanistanPakistan border (e.g. Peshawar, Chaman, Quetta) and well-defined "Bara" (smuggled goods) markets in other large cities of Pakistan provide support to these assertions.

The estimates generated by this study indicate that aggregate unofficial re-exports from Afghanistan to Pakistan amounted to Rs. 83.7 billion in 1997, of which a subset is smuggling through ATT, valued at Rs. 4.5 billion in 1996/97. The study's methodology, based on interviews with traders and loaders, informal assessment of inventories of transshipment warehouses, and counting and valuing goods carried on trucks across the border, was not able to distinguished between ATT-bound goods crossing back into Pakistan and other re-exports. This was because goods cross the Pakistani border with most of the ATT packaging and seals removed, not only via the main roads but also through smaller passes and routes on animal backs, with the refugees population moving back and forth, and even on backs of people. The full value of the ATT could be taken as the upper bound of the estimated smuggling through the transit facility from Afghanistan into Pakistan. ${ }^{9}$ It is conceivable that given the poor economic conditions in Afghanistan and the need for all types of imported goods due to lack of domestic production, a portion of goods coming via ATT do consist of real imports into Afghanistan. On the other hand, the list of ATT items, especially non-essential products such as electrical goods, audio/video cassettes, tape-recorders, toiletries, glass ware and crockery, battery cells, chewing gum, cosmetics etc. do suggest that a large portion of the ATT is not being used to supply imported goods into a war-torn country, but is a channel of evading tariff and non-tariff barriers and of smuggling goods into Pakistan.

\section{Reasons for Smuggling from Afghanistan into Pakistan}

There are several reasons why there is such a large inflow of unofficial re-exports from Afghanistan into Pakistan, including the following:

- Although re-export trade/smuggling between the two countries has existed for decades, the recent conflict and chaos in Afghanistan seem to be facilitating expansion of this activity, leading to a complete breakdown of formal economic institutions and has increasing informalization and criminalization of the economy. In a war economy, trading activities are among the few remaining avenues for making a reasonable living, particularly in urban areas.

- The war has also changed the structure of other economic sectors, such as agriculture. The lack of economic alternatives has led to tremendous increases in poppy production in a few provinces in Afghanistan, which has made the country into the largest producer of poppy, supplying half of world demand for opiates. While poppy production is a source of income for farmers, the manufacture and trade in opiates is

\footnotetext{
9 But this upper-bound could still be a gross underestimate because of the under-invoicing in the ATT.
} 
believed to be creating huge illegal incomes and profits for the large drug dealers. It is widely believed that smuggling into Pakistan and other neighboring countries is used a means of laundering illegal drug money.

- There may have been an increase in smuggling from Afghanistan in the last few years due to the improvement in security conditions after the Taliban takeover of southern and eastern Afghanistan. There are indications that movement of goods has become much easier under the Taliban rule via land routes from cities in western Afghanistan (Islam Qila and Torghundi) to southern and eastern Afghanistan. Trade has also been facilitated by opening of trade routes from Iran and the Central Asian Republics.

- The border between Pakistan and Afghanistan, approximately $1500 \mathrm{~km}$ long, is easily penetrable, and largely unmonitorable. This facilitates the movement of goods and people between the two countries.

- The war has displaced a large number of Afghans, approximately one million of whom live as refugees in Pakistan, whose family members move back and forth between the two countries. A large number of wealthy Afghans have set up trade and businesses enterprises in border towns in Pakistan and in neighboring countries. The war and long-term displacement of the population in Afghanistan has led to the meshing of Afghan and Pakistani population in parts of North West Frontier Province and Balochistan. It is therefore become difficult to draw strict economic boundaries, corresponding to geographical boundaries between the two countries.

- Interviews with Afghan traders indicate that Afghanistan-Pakistan re-export trade not only supplies Pakistan's markets, is also an important conduit for unofficial regional trade to markets in the east (e.g. India, Bangladesh) and to markets in the west and north (e.g. Iran, Central Asian Republics). If this is true, then the growth in smuggling could partly be attributed to wider regional demand for these goods.

- There is high demand for imported consumer goods in Pakistan. The increase in incomes of middle class and lower middle class households in Pakistan over the past two decades, especially based on workers' remittances from the Middle East, and the exposure to a wide array of consumer goods, seems to have increased the demand for smuggled imports in Pakistan.

- Trade and tariff policies in Pakistan have historically provided incentives for smuggling. Pakistan had an import-substituting industrialization policy in the first few decades of its existence. Although tariff and non-tariff barriers have come down substantially in recent years and there has been considerable liberalization of the trade regime, the tariff structure still provides ample impetus for smuggling. Many of the items which are unofficially imported into Pakistan, through the ATT or other means, have high statutory tariff rates, providing strong incentives for smuggling. Our estimates show that market prices of certain popular smuggled goods are on average 
$30-40 \%$ lower than their corresponding landed prices under official imports. ${ }^{10}$ The main reason for this has been high tariffs and sales taxes on these goods. On the other hand, the costs of smuggling are fairly low, ranging from 5-17\% (average of $10-12 \%$ ), which further motivates smugglers to supply goods through unofficial channels.

- Issues related to poor governance in Pakistan also have contributed to the escalation in smuggling. Although the terrain on the Afghanistan-Pakistan border is difficult to patrol, there is in any case poor enforcement of border controls. According to Pakistan government officials, if there were tight border controls and good law enforcement, it would be possible to seize around $20 \%$ of total smuggling across the border. But the total value of seized goods in 1996/97 by the Customs department and Frontier Corps, the two main agencies involved in controlling smuggling, was less than one percent of estimated total cross-border smuggling between Afghanistan and Pakistan. ${ }^{11}$ Data provided by these agencies show that even in previous years, these agencies were never able to capture more than $10 \%$ of the value of the ATT, which is indicative of weak enforcement of border controls.

- Other measures to control smuggling also have not met with much success. For instance, the order issued in 1982 to provide copies of Letters of Credit $(\mathrm{L} / \mathrm{Cs})$ and ATT permits to Pakistani government officials did not produce the desired results. ${ }^{12}$ Traders by-passed this regulation by presenting forged and fake documents. Countermeasures to control ATT smuggling also failed, as traders were able to bribe government officials on both sides of the border to furnish the necessary papers. A large number of legal petitions have been filed against measures taken to combat smuggling through ATT. In some cases, Pakistani courts have given conflicting judgments, which made the task of the law enforcement agencies more difficult.

- Contradictory policy positions taken by different government ministries in Pakistan seem to hamper efforts to control smuggling. For instance, the Ministry of Commerce and Central Board of Revenue, directly in charge of controlling smuggling, are reported to have been discussing measures, within their organizations and with Afghan officials, to curb smuggling by bringing about major changes in the ATTA. On the other hand, newspaper reports and discussions with officials indicate that the government ministries dealing with political and foreign policy aspects of Afghanistan-Pakistan relations are reluctant to bring about major changes in the status quo due to the fluid political situation in the country.

${ }^{10}$ Landed prices were calculated as the C\&F price of selected brands of imported goods plus customs duty, sales tax, $5 \%$ handling cost, and a $10 \%$ profit margin.

11 The Customs department seized Rs. 428.6 million worth of contraband goods and the Frontier Corps seized Rs 177.3 million, respectively, during 1996-97.

12 Details of various measures to combat smuggling through the ATT and their results are discussed in Saleem (undated). 


\section{IMPACT OF TRADE ON THE ECONOMIES OF AFGHANISTAN AND PAKISTAN}

In the absence of usable quantitative data, analysis of the economic impact of trade between Afghanistan and Pakistan must be based on impressionistic assessments. However, it is clear that the bilateral trade has been having a major impact on Afghanistan's economy and a significant impact of Pakistan's as well.

\section{Afghanistan:}

Afghanistan-Pakistan trade seems to be providing income-generation and employment opportunities in southern, western, and eastern Afghanistan and is probably contributing to the observed prosperity in cities such as Herat, Kandahar, and Jalalabad. The re-export trade seems to be creating business opportunities for Afghan traders, transporters, packaging companies, and shipping and handling companies. In addition, the unofficial trade in locally-produced (mainly agricultural) goods seems to be generating incomes for farmers. Unofficial exports such as carpets, Afghan jewelry, hand-crafted precious stones, and other handicrafts from the small manufacturing and handicrafts sector provide incomes to artisans and handicraft-makers. Trade and business activities seem to be complementing the active "bazaar" money changers and financiers in Afghanistan.

The bilateral trade also seems to be providing needed essential goods for the warravaged Afghan economy. Food (mainly staple food items), construction materials, housing supplies, medicines, fertilizers etc. are among the goods being imported into Afghanistan from Pakistan. Availability of essential goods also helps in keeping down prices and partly providing for basic needs of large segments of the population. Parts of eastern and southern Afghanistan exhibit characteristics of a small open economy, such as domestic prices closely aligned to cross-border prices and with vulnerability to supply shocks and changes in exchange rate policies in Pakistan. Thus changes in tariff and trade policies in Pakistan and strict imposition of smuggling control measures could have a substantial impact on incomes and employment in Afghanistan.

The authorities in Afghanistan levy a nominal charge of one percent (called "Maafi") on unofficial re-exports going into Pakistan. On the estimated total value of \$2 billion in re-exports, they would be collecting about $\$ 20$ million annually. The re-export trade is reportedly conducted with the full knowledge Afghan authorities, who charge a different rate if goods are primarily meant for the Afghan market. The Taliban authorities also charge customs duty on goods coming into Afghanistan through air and land routes. A joint UNDP-World Bank study in 1977 conservatively estimated revenue collection of $\$ 50$ million from trade-related activities in Afghanistan. Hence the Afghan authorities may be collecting approximately $\$ 75$ million from the Afghanistan-Pakistan trade. 


\section{Pakistan}

Large segments of agriculture, certain manufacturing industries, and certain categories of traders in Pakistan seem to be benefiting from the cross-border trade with Afghanistan. Although no serious research has been conducted on this issue, newspaper reports suggest that approximately half of the flour mills in Punjab and NWFP are running mainly to meet demand for flour and related products in Afghanistan. Similarly, the demand for sugar, ghee/cooking oil, garments, plastic products, construction materials, cement, glass products, medicines, fertilizers, etc. in Afghanistan must be creating incomes for these segments of Pakistan's industrial sector. In addition, cheap imports of smuggled (polyester yarn, dyes and chemicals, auto parts) and legally imported (wood and timber, metal scrap, etc.) industrial inputs from Afghanistan reduce the cost of production for industry in Pakistan. It is conceivable that in a post-conflict period, the massive reconstruction needs of Afghanistan may give a boost to various types of industries in Pakistan. In addition, low-cost smuggled goods benefit consumers by providing a wider range of products and have stabilized retail prices for many consumer products.

However, the large-scale smuggling of consumer durables (e.g. televisions, tape recorders, air-conditioners, etc.), tires/tubes, art silk piece goods, auto parts, bicycles, batteries, etc. has caused considerable damage to these industries in Pakistan. The study covered the impact on three Pakistani industries, automotive batteries, air-conditioners, and tires, in some detail. Industry sources say they are losing markets in Pakistan because they are unable to compete with low cost smuggled goods. For example, smuggled goods prices were on average lower than prices of domestic goods; $12-40 \%$ lower for automotive batteries, $20 \%$ lower for air-conditioners, and $10-15 \%$ lower for tires. Lowering of sales taxes and/or customs duties by the government have made local goods somewhat more price competitive, but still the smuggled goods are cheaper. Local industrialist feel that fiscal measures to combat smuggling are not enough and that these need to be backed up with strong administrative measures to physically stop smuggling at the borders. There has been also growth in the manufacture of falsely-branded goods, resembling imported items under unofficial re-exports, which have further damaged legal manufacturing activities in Pakistan.

One of the most significant negative impact of smuggling has been on government revenues. Pakistan still relies heavily on customs duties and sales tax on imports. It has been estimated that tax evasion through tax-free imports under the ATT, primarily meant for Pakistani markets, and other types of smuggling is substantial. However, estimates of revenue losses are in a wide range. At the upper end, estimates of revenue losses based on statutory rates of Customs duties and sales tax on imports, for an estimated Rs. 83 billion worth of re-exports, are in the range of Rs. $60-67$ billion. ${ }^{13}$ At the

\footnotetext{
${ }^{13}$ These are based on statutory tax rates and sales tax on imports of $12.5 \%$ for the fiscal year $1996 / 97$. The statutory rates on the list of smuggled goods generated for this study, were in the range of $10-45 \%$ during 1996/97. However, the bulk of the goods were in the $35-45 \%$ tariff rates range and did not
} 
lower end, estimated losses would be approximately Rs. 8-9 billion, equivalent to $0.3 \%$ of GDP, based on the assumption that the government would be setting optimal tax rates based on the average cost of smuggling of $10-12 \%$. Realistic estimates could be somewhere in between and would largely depend on the efforts of revenue collection and law enforcement agencies in Pakistan.

\section{ISSUES FOR FURTHER RESEARCH}

This study was limited because field work could only be conducted in Pakistan. Many questions could not be answered because of this limitation. Further research is needed to fully understand the impact of bilateral trade with other neighboring countries on Afghanistan's economy.

1. This study covered only unofficial trade in "goods", but it is equally important to understand the extent and mechanisms of trade in "bads", i.e. narcotics and arms. The latter type of trade is often done under the cover of trade in goods. The size of trade in illegal and contraband items has implications for exchange markets as well as for the underground economies of the region.

2. A more regional perspective on unofficial trade would be important in future work. During the course of this study, it was found that some of the goods smuggled into Pakistan from Afghanistan also find their ways to Indian and Iranian markets. Hence, a regional analysis of trade would provide important insights into the magnitude, routes and mechanisms of Afghanistan's trade with other countries in South and Central Asia.

3. There is ample evidence that open currency markets in Pakistan are facilitating illegal trade activities. It would be interesting to study in more detail the functioning of these currency markets and their impact on unofficial trade. More research is also needed to find out the means by which trade is financed and the impact on balance of payments of regional economies.

4. The provinces of Balochistan and NWFP in Pakistan, through which transshipment and illegal trade activities take place, are heavily influenced by these activities. A comparative study of these provincial economies should be able to provide a detailed account of the costs and benefits of official and unofficial trade. This kind of study can also ascertain whether there are local or even nation-wide or international interest groups who are actively involved and facilitate such activities.

enjoy any tariff concessions. Our estimates based on statutory rates are therefore on the high side because of these reasons. 
5. Since the present study was conducted on the Pakistani side of the border, it only looked at issues associated with Afghanistan-Pakistan trade. A more complete study of Afghanistan's trade with other neighboring countries (e.g. Iran, Turkmenistan, Uzbekistan and Tajikistan) would provide insights into Afghanistan's trade relations with these countries and the impact on these economies.

6. The impact of trade on the economy of Afghanistan was only dealt with in cursory manner in this study. A more detailed study should be conducted to look at trade-related income-generation activities, and other impacts of trade with neighboring countries and the region, on Afghanistan's economy.

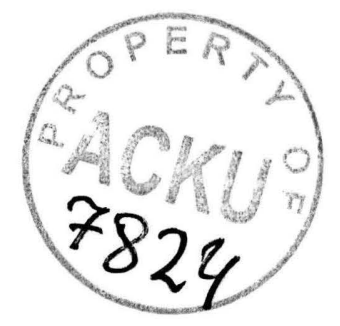




\section{$\underline{\text { References }}$}

Amiri, Abdul Haq, 1993, Afghanistan's Economic Prospects after Soviet Occupation and Jihad, 1979-1993, Master's thesis, Wright State University, USA.

Fry, Maxwell, J. 1974, The Afghan Economy: Money, Finance and the Critical Constraints to Economic Development, E. J. Brill, Leiden, Netherlands.

Khan, Ghani Muhammad, 1972, Afghanistan's Transit Trade Through Pakistan and the Unrecorded Transactions at Landikotal, Board of Economic Inquiry, University of Peshawar, Pakistan.

Ostrom, Kjell, 1997, Understanding the Economy of Afghanistan, Swedish International Development Cooperation Agency, Stockholm, Sweden.

Saleem, Muhammad, undated, Brief Regarding Afghan Transit Trade, Collector of Customs (Exports), Karachi.

The World Bank, 1998, Post-Conflict Reconstruction: The Role of the World Bank, Washington, D. C.

The World Bank, 1997, Study of Afghanistan-Pakistan Trade Relations, Consultant's report, Islamabad, Pakistan.

UNDP, 1997, Political Economy in Afghanistan - District Profiles, unpublished report, jointly conducted by UNDP (Afghanistan) and The World Bank (Islamabad Office). 


\section{Annex 1. Details of Afghanistan-Pakistan Trade}

Table A1: Structure of Legal Exports from Pakistan to Afghanistan (\%)

\begin{tabular}{|l|l|l|l|l|l|l|}
\hline Name of Products & $1985-86$ & $1990-91$ & $1993-94$ & $1995-96$ & $1996-97$ & $1997-98$ \\
\hline Rice & 0 & 8.4 & 44.6 & 49.9 & 56.1 & 15.6 \\
\hline Fruits & 10.9 & 1.9 & 2.1 & 1.9 & 4.7 & 4.0 \\
\hline Sugar & 3.7 & 16.3 & 1.3 & 0.4 & 0.0 & 8.1 \\
\hline Misc. Food Items & 0.2 & 18.4 & 20.4 & 5.2 & 2.1 & 5.1 \\
\hline Cigarettes & 53.1 & 0.0 & 0.0 & 0.0 & 0.0 & 0.0 \\
\hline Salt & 0.0 & 0.0 & 0.5 & 0.7 & 0.6 & 0.9 \\
\hline Ghee & n.a. & n.a. & n.a. & 0.4 & 0.0 & 10.0 \\
\hline Chemicals & 4.8 & 3.8 & 6.0 & 0.0 & 0.0 & 0.2 \\
\hline Leather \& Prod. & 1.2 & 4.3 & 3.5 & 0.2 & 0.0 & 0.2 \\
\hline Textile Yarn/Products & 8.8 & 16.9 & 12.1 & 9.6 & 5.0 & 1.5 \\
\hline Garments & 1.1 & 1.3 & 1.0 & 0.0 & 0.6 & 1.0 \\
\hline Cement & n.a. & n.a. & n.a. & 0.0 & 0.2 & 1.7 \\
\hline Glass Products & 0.9 & 18.5 & 0.4 & 0.0 & 1.0 & 1.4 \\
\hline Construction Materials & n.a. & n.a. & n.a. & 2.5 & 0.8 & 3.9 \\
\hline Metal Products & 6.3 & 4.7 & 5.9 & 0.4 & 0.0 & 0.4 \\
\hline Machinery & 1.0 & 1.2 & 0.6 & 0.8 & 0.6 & 0.6 \\
\hline Plastic Products & n.a. & n.a. & n.a. & 19.9 & 22.0 & 31.8 \\
\hline Miscellaneous & 7.9 & 4.3 & 1.7 & 8.1 & 6.2 & 13.8 \\
\hline & & & & & & \\
\hline Total (Rs. Million) & 323.6 & 68.5 & 464.0 & 449.8 & 595.9 & $1,352.3$ \\
\hline Source: Feder Burcau & af Statistiss GoP. & & &
\end{tabular}

Source: Federal Bureau of Statistics, GOP.

Table A2: Distribution of Unofficial Exports from Pakistan to Afghanistan, 1997 (\%)

\begin{tabular}{|l|l|l|l|l|l|l|}
\hline Items & Torkhum & Gandab & $\begin{array}{l}\text { Chaman/ } \\
\text { Weish }\end{array}$ & $\begin{array}{l}\text { Angoor } \\
\text { Ada }\end{array}$ & Parachinar & Total \\
\hline Flour & 35.6 & 6.6 & 32.6 & 11.0 & 13.8 & 23.37 \\
\hline Rice & 19.4 & 13.7 & 14.2 & 13.7 & 17.2 & 15.43 \\
\hline Ghee & 0.0 & 7.1 & 15.2 & 11.7 & 15.3 & 11.49 \\
\hline Sugar & 0.0 & 8.9 & 3.8 & 16.0 & 10.3 & 6.32 \\
\hline Pulses & 0.0 & 12.0 & 3.0 & 8.2 & 2.9 & 4.40 \\
\hline Cotton & 0.0 & 0.0 & 0.3 & 2.9 & 0.6 & 0.46 \\
\hline Cloth & 0.0 & 38.0 & 0.0 & 0.0 & 0.0 & 6.22 \\
\hline Medicines & 24.7 & 0.0 & 0.0 & 0.0 & 0.0 & 3.48 \\
\hline Cement & 0.0 & 0.0 & 0.1 & 0.9 & 3.7 & 0.87 \\
\hline Fertilizer & 9.5 & 4.3 & 8.4 & 13.0 & 10.4 & 8.65 \\
\hline Petroleum Products & 1.6 & 0.0 & 5.7 & 5.9 & 9.1 & 4.89 \\
\hline Others & 9.1 & 9.5 & 16.7 & 16.7 & 16.7 & 14.42 \\
\hline & & & & & & \\
\hline Total (Rs. Million) & 1222.6 & 1420.8 & 3646.2 & 629.9 & 1761.4 & 8680.6 \\
\hline
\end{tabular}

Source: World Bank (1997). 
Table A3: Structure of Legal Imports from Afghanistan to Pakistan (\%)

\begin{tabular}{|l|l|l|l|l|l|l|}
\hline Name of Products & $1985-86$ & $1990-91$ & $1993-94$ & $1995-96$ & $1996-97$ & $1997-98$ \\
\hline Lentils & 8.7 & 7.3 & 5.4 & 23.6 & 10.8 & 13.0 \\
\hline Fresh \& Dried Fruits & 54.2 & 46.1 & 35.6 & 40.7 & 26.5 & 21.6 \\
\hline Herbs \& Spices & 10.1 & 6.8 & 3.7 & 5.8 & 3.8 & 2.4 \\
\hline Misc. Food Items & 0.2 & 0.3 & 0.5 & 0.8 & 0.3 & 0.7 \\
\hline Leather & 17.0 & 6.8 & 8.4 & 3.2 & 8.7 & 4.0 \\
\hline Carpets & 4.8 & 0.7 & 0.9 & 0.4 & 0.2 & 0.0 \\
\hline Wood & 0.0 & 3.3 & 0.0 & 12.3 & 34.1 & 28.7 \\
\hline Cotton & 0.0 & 0.0 & 0.0 & 1.9 & 3.2 & 12.4 \\
\hline Metal Waste & 1.0 & 19.3 & 34.0 & 4.4 & 1.1 & 1.9 \\
\hline Chemicals & 2.7 & 1.9 & 2.8 & 2.1 & 0.9 & 4.2 \\
\hline Tools/parts & 0.0 & 0.0 & 0.0 & 1.7 & 8.1 & 8.0 \\
\hline Vehicles & 0.2 & 0.3 & 0.3 & 0.0 & 0.0 & 0.1 \\
\hline Miscellaneous & 1.0 & 7.1 & 8.3 & 3.2 & 2.4 & 3.1 \\
\hline & & & & & & \\
\hline Total (Rs. Million) & 273.7 & 152.7 & 329.9 & 755.0 & $1,272.9$ & $1,190.2$ \\
\hline
\end{tabular}

Source: Federal Bureau of Statistics, GOP.

Table A4: Distribution of Unofficial Imports from Afghanistan to Pakistan, 1997 (\%)

\begin{tabular}{|l|l|l|l|l|l|l|}
\hline Items & Torkhum & $\begin{array}{l}\text { Chaman/ } \\
\text { Weish }\end{array}$ & $\begin{array}{l}\text { Angoor } \\
\text { Ada }\end{array}$ & $\begin{array}{l}\text { Miran } \\
\text { Shah }\end{array}$ & $\begin{array}{l}\text { Shah-i- } \\
\text { Salim }\end{array}$ & Total \\
\hline Fresh \& dried fruits & 60.3 & 44.4 & 36.6 & 38.7 & 2.4 & 36.00 \\
\hline Vegetables & 0.0 & 3.0 & 12.3 & 8.1 & 0.0 & 4.80 \\
\hline Spices & 0.8 & 2.1 & 6.5 & 2.5 & 1.9 & 2.66 \\
\hline Live Animals & 0.0 & 0.0 & 0.0 & 0.0 & 9.7 & 1.62 \\
\hline Animals skins & 9.7 & 7.8 & 15.3 & 8.1 & 3.1 & 8.24 \\
\hline Wool & 0.0 & 2.0 & 2.4 & 1.1 & 0.0 & 1.38 \\
\hline Precious stones & 0.0 & 0.0 & 0.0 & 0.0 & 65.0 & 10.87 \\
\hline Timber/wood & 0.0 & 0.0 & 1.5 & 4.9 & 0.0 & 1.40 \\
\hline Carpets & 11.7 & 18.9 & 0.0 & 17.0 & 0.6 & 12.32 \\
\hline Scrap metal & 0.0 & 4.2 & 3.1 & 1.2 & 0.3 & 2.39 \\
\hline Others & 17.5 & 17.6 & 22.4 & 18.4 & 17.0 & 18.31 \\
\hline & & & & & & \\
\hline Total (Rs. Million) & 369.9 & 2148.4 & 752.1 & 1355.2 & 929.2 & 5554.9 \\
\hline
\end{tabular}

Source: World Bank (1997). 
Table A5: Afghan Transit Trade Imports 1985/86-1996/97 (Rs. Million)

\begin{tabular}{|c|c|c|c|c|c|c|c|c|c|c|c|c|c|}
\hline Items & $1985-86$ & $1986-87$ & $1987-88$ & 1988-89 & $1989-90$ & $1990-91$ & $1991-92$ & $1992-93$ & 1993-94 & $1994-95$ & $1995-96$ & 1996-97 & $1997-98$ \\
\hline Textiles & 82.38 & 31.85 & 216.96 & 268.01 & 280.54 & 434.3 & 277.4 & 1127.5 & 2908.3 & 2018 & & & \\
\hline Yarn & 210.7 & 276.18 & 259.02 & 146.84 & 120.68 & 119.74 & 126.03 & 332.4 & 360.03 & 33.94 & & & \\
\hline Tires and Tubes & 89.84 & 325.83 & 451.64 & 173.36 & 238.75 & 207.43 & 56.9 & 188.17 & 126.9 & 0.78 & 198.37 & 2.42 & \\
\hline Electrical goods & 19.89 & 14.57 & 14 & 23.74 & 31.31 & 69.27 & 113.43 & 259.5 & 358.8 & 395.57 & 664.9 & 789.71 & 642.85 \\
\hline Betel nuts & 3.46 & 0.79 & 0.15 & 0 & 0 & 0 & 0 & 0 & 14.23 & 5.66 & 8.77 & & \\
\hline Crockery & 0 & 2.92 & 10.43 & 23.22 & 23.62 & 17.4 & 49.59 & 214.84 & 676.8 & 320.2 & 304.2 & 433.9 & 631.46 \\
\hline Air conditioners & 0 & 0.98 & 7.07 & 6.67 & 1.19 & 14.65 & 36.79 & 63.51 & 327.68 & 528.9 & 4.6 & & \\
\hline Iron \& Steel & 19.5 & 31.34 & 13.59 & 8.13 & 6.35 & & & & 57.64 & 23.8 & 0 & 151.9 & \\
\hline Washing Machines & 0 & 0.28 & 0.28 & 0 & 0 & & & & 0.22 & 2.63 & 2.45 & 1.95 & \\
\hline Tape recorders & 2.1 & 2.1 & 0 & 0 & 0 & & & & 0.12 & 17.5 & 26.2 & 173.8 & 175.66 \\
\hline Audio/Video Cassettes & 1.37 & 1.37 & 0 & 0 & 0 & & & & & & & 79.8 & 163.97 \\
\hline Television & & & & & & 1.9 & 40.23 & 171.67 & 954.7 & 1372 & & & \\
\hline Auto parts & 6.4 & 18.29 & 37.14 & 39.94 & 20.56 & 10.65 & 23.61 & 149.15 & 737.81 & 536.63 & 6.58 & & 27.15 \\
\hline Batteries & 0.8 & 3.11 & 39.96 & 63.2 & 26.55 & & & & 24.19 & 64.73 & 12.98 & & 484.39 \\
\hline Tea & 94.96 & 58.96 & 79.97 & 83.51 & 15.13 & 13.15 & 26.7 & 49.3 & 415 & 635.2 & 123.7 & 205.26 & 520.19 \\
\hline Toiletries & 0.7 & 0 & 0 & 0 & 0 & 0 & 0 & 51.03 & 126.31 & 366.7 & & & 114.19 \\
\hline Machinery & 11.45 & 23.31 & 51.99 & 41.41 & 2.48 & & & & 19.89 & 43.25 & 67.81 & 109.78 & 41.36 \\
\hline Vehicles/Cars & 21.12 & 34.62 & 39.37 & 19.47 & 0.65 & & & & 22.29 & 58.77 & 32.37 & 9.84 & \\
\hline All others & 196.91 & 124.25 & 125.81 & 213.81 & 215.83 & 168.4 & 263.6 & 582.7 & 887.42 & 1720.4 & 2646.14 & 2680.53 & 6153.17 \\
\hline Total & 754.87 & 946.21 & 1345.95 & 1111.31 & 983.64 & 1050.3 & 1037.7 & 3329.23 & 8004.1 & 8139 & 4090.3 & 4559.09 & 8954.39 \\
\hline
\end{tabular}

Source: Collectorate of Customs (Export), Karachi. 


\section{Box 1: Items banned under ATT}

Periodic notifications issued by the Customs Department of the Government of Pakistan, banned the following 17 items from the Afghan Transit Trade over the period 1992-95. Ban on these items was formalized in SRO 135(I)/96 dated February 12, 1996. These items are:

June 1992

Tires/tubes, cigars/cigarettes.

November 1994 Yarn, black tea, PVC/PMC pipes, dyes/chemicals, polyester-materialized film.

February 1995 Refrigerators, air conditioners, television and parts, ball bearings, soap/shampoo, auto parts, timers/capacitors, artsilk fabrics.

September $1995 \quad$ vegetable ghee, cooking oil.

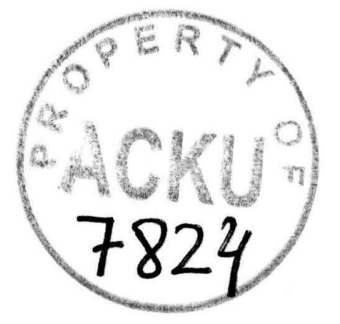

